We therefore consider that our filter installations give a degree of sterility which for practical purposes can be regarded as total. We still would hesitate to describe it as 100 per cent!

$$
\text { Yours faithfully, }
$$

J. B. Brooksby

R. F. SELLERS

W. BRUCE

Animal Virus Research Institute,

Pirbright,

Woking,

Surrey.

${ }^{1}$ Thorne, H. V., and Burrows, T. M., J. Hyg., 58409 (1960).
Singular Mistake

SIr,--Although the Shorter Oxford English Dictionary gives the word nare ("now only archaic"), anyone who uses it as the singular of nares in a scientific communication (Nature, 228, 873; 1970) deserves a kick on each natisor both nates.

Yours faithfully,

L. Harrison MatThews

The Old Rectory,

Stansfield, Sudbury, Suffolk.

\title{
Announcements
}

\section{University News}

Professor R. W. G. Hunt, Kodak Research Laboratories, has been reappointed visiting professor in the Department of Ophthalmic Optics at the City University.

Dr P. J. Lachmann has been appointed to the chair of immunology at the Royal Postgraduate Medical School, University of London; Dr W. Plowright has been appointed to the chair of veterinary microbiology and parasitology tenable at the Royal Veterinary College, and Dr J. A. S. Smith has been appointed to the chair of chemistry tenable at Queen Elizabeth College. The title of professor of computer systems has been conferred on Dr P. T. Kirstein in respect of his post at the Institute of Computer Science.

Professor P. W. Richards, University College of North Wales, has been appointed Royal Society visiting professor to the Department of Botany, Fourah Bay College, University of Sierra Leone.

\section{Appointments}

Mr Frank Horne, who recently retired as director of the National Institute of Agricultural Botany, has been elected a vice-president of the institute.

Dr Julius H. Comroe, director of the Cardiovascular Research Institute, University of California, San Francisco, has been appointed to the National Advisory Heart and Lung Council of the US National Heart and Lung Institute.

Major-General James W. Humphreys has been appointed director of life sciences in the Office of Manned Space Flight, US National Aeronautics and Space Administration Headquarters. This new post entails responsibility for all NASA activities in the life sciences.

Dr Sydney Jones, member for engineering and research of the British Railways Board, has been elected chairman of council of the Sira Institute, in succession to $\mathbf{M r}$ William Storey who has retired. 'This will be Dr Jones's second term of office as chairman.

\section{Miscellaneous}

Miss Peggy Hodges, who is responsible for guided weapon simulation and systems studies at the Stanmore establishment of Marconi Space and Defence Systems, has won the $\mathbf{1 9 7 0}$ Whitney Straight award for her contributions to guided weapon and avionics technology. The award consists of a bronze sculpture and not less than $£ 200$.

Applications are invited by the council of the Institution. of Electrical Engineers for the 1971 Karl Heinz Gyr and Heinrich Landis commemorative prize. The prize will be awarded for an outstanding contribution to the advancement of electrical or electronic science or engineering, and is intended by the donors to help the winner to further his knowledge and experience in his field of study. Further information can be obtained from the Secretary, Institution of Electrical Engineers, Savoy Place, London WC2R 0BL.

Erratum. In the article "Differential Inhibition of Red Cell Carbonic Anhydrase Isozymes in Hyperthyroidism" on page 1197 of this issue of Nature, please ignore Table 1 and all the figures, which were included as a result of an editorial error. Table 2 should be regarded as Table 1.

ERratum. In the article entitled "Drug-induced Release of ${ }^{3} \mathrm{H}$-Norepinephrine and ${ }^{3} \mathrm{H}$-Serotonin from Brain. Slices" by K. Y. Ng, T. N. Chase and I. J. Kopin (Nature, $228,468 ; 1970)$, line 1 of the penultimate paragraph should read "The net efflux of labelled monoamines ...". The sentence beginning on line 18 of the same paragraph should read "The direct releasing action of amphetamine ...". The first sentence of the final paragraph should read "It is likely that exogenous norepinephrine and serotonin enter the relatively abundant dopaminergic terminals in striatal tissue...".

\section{International Meetings}

January 7-8, Chemical Society Molecular Beam Kinetics Group Meeting, Abingdon (Dr A. R. Burgess, Department of Chemical Engineering, University College London, Torrington Place, London WC1E $7 \mathrm{JE})$.

January 28-February 2, Asian Congress of Nutrition, Hyderabad (Dr P. G. Tulpule, National Institute of Nutrition, Hyderabad 7, India).

March 16-17, Computers in Medicine, Blackburn (Dr J. Rose, College of Technology, Blackburn BB21 LH).

March 22-April 2, Circuit Theory, Bangor (Secretary, Institution of Electrical Engineers, Savoy Place, London WC2R 0BL). 